\title{
Removal of ammonium and nitrate in recirculating aquaculture systems by the epiphyte Stigeoclonium nanum immobilized in alginate beads
}

\author{
Norulhuda Mohamed Ramli ${ }^{1,2, *}$, M. C. J. Verdegem ${ }^{1}$ F. M. Yusoff ${ }^{3,4}$, M. K. Zulkifely ${ }^{4}$, \\ J. A. J. Verreth ${ }^{1}$ \\ ${ }^{1}$ Aquaculture and Fisheries Group, Wageningen University, $6700 \mathrm{AH}$ Wageningen, The Netherlands \\ ${ }^{2}$ Department of Biological and Agricultural Engineering, Faculty of Engineering, Universiti Putra Malaysia, 43400 Serdang, \\ Selangor, Malaysia \\ ${ }^{3}$ Laboratory of Marine Biotechnology, Institute of Bioscience, Universiti Putra Malaysia, 43400 Serdang, Selangor, Malaysia \\ ${ }^{4}$ Department of Aquaculture, Faculty of Agriculture, Universiti Putra Malaysia, 43400 Serdang, Selangor, Malaysia
}

\begin{abstract}
Incorporation of microalgae in recirculating aquaculture systems (RAS) would absorb the inorganic nitrogen and phosphorus, thus potentially contributing to water purification. Immobilization or entrapment of microalgal cells in spherical gels is a potential method to incorporate microalgae in the RAS. Filamentous microalgae are presumed to suit the immobilization technique because the gels can serve as substrates for the microalgae to attach. In the first experiment of this study, growth and nitrogen uptake of Stigeoclonium nanum, a filamentous microalga, was compared when cultured using an immobilization technique or in a normal suspension. In the second experiment, immobilized $S$. nanum was cultured in 4 media with different total ammonia nitrogen (TAN) and nitrate-nitrogen $\left(\mathrm{NO}_{3}-\mathrm{N}\right)$ concentrations. The results showed a significantly higher algal growth and TAN removal by $S$. nanum immobilized in alginate than for $S$. nanum in free suspension culture. When both TAN and $\mathrm{NO}_{3}-\mathrm{N}$ were added to the culture medium, the uptake of TAN by immobilized $S$. nanum was significantly more efficient than $\mathrm{NO}_{3}-\mathrm{N}$ uptake. Our results indicated that $S$. nanum was able to grow immobilized in a medium, exhibiting a higher growth and TAN uptake than when the algae were in free suspension. $S$. nanum preferred ammonium over nitrate, which is suitable for RAS that require removal of the total ammonia which is produced by fish and by organic decomposition in the system.
\end{abstract}

KEY WORDS: Alginate beads - Filamentous epiphyte - Immobilization - Nitrogen uptake · Stigeoclonium nanum · Aquaculture waste

\section{INTRODUCTION}

A recirculating aquaculture system (RAS) is a more sustainable aquaculture practice than a flow-through system considering that the waste discharge into the environment can be better controlled, the volume of water used per $\mathrm{kg}$ fish produced can be optimized, the biosecurity can be increased, and reliance on disinfectants can be reduced (Piedrahita 2003, Verdegem et al. 2006, Martins et al. 2010). Water purifi-

*Corresponding author: norul49huda@gmail.com cation in RAS works by removing solid and metabolic wastes which originate from uneaten feed and fish fecal and non-fecal metabolic losses. Total ammonia nitrogen (TAN: ammonia, $\mathrm{NH}_{3}+$ ammonium, $\mathrm{NH}_{4}{ }^{+}$) is a toxic nitrogenous metabolic waste material. It is removed by nitrification, during which ammonium is converted to nitrite and subsequently to nitrate. Therefore, nitrate accumulation becomes a common problem in RAS. Since nitrate is a fish growthinhibiting substance (vanRijn et al. 2006, Davidson et

(C) The authors 2017. Open Access under Creative Commons by Attribution Licence. Use, distribution and reproduction are unrestricted. Authors and original publication must be credited. 
al. 2014), nitrate must be removed to maintain optimal water quality in RAS. The most common method of nitrate removal is by partial water exchange; however, this method is not sustainable because nitrate discharge will pollute the environment (vanRijn et al. 2006, Martins et al. 2009).

Because microalgae are capable of absorbing ammonium and nitrate, they are used widely in wastewater treatment (Abdel-Raouf et al. 2012). Dortch (1990) explained that ammonium would be directly assimilated into amino acids, and thus would be taken up by algae more efficiently and with more energy savings than nitrate. More energy is needed for nitrate reduction to nitrite and subsequently to ammonium compared to direct uptake of ammonium by algae (Needoba et al. 2004, Perez-Garcia et al. 2011). However, preference for ammonium or nitrate might also occur as a result of genetic and environmental conditions such as light, carbon, and heavy metal presence (Raven et al. 1992, Podevin et al. 2015).

Water quality in RAS is mainly controlled by heterotrophic and autotrophic bacteria (Ebeling et al. 2006), and the application of microalgae in RAS is limited. One example is the use of an algal turf scrubber (ATS), relying on a periphytic biofilm community including bacteria, microalgae, fungi, and protozoans, to maintain water quality in RAS (Valeta \& Verdegem 2015). However, an ATS requires a large surface area to perform efficiently. Therefore, there is a need to find another approach which could increase the efficiency in terms of nutrient uptake and space utilization. Thus, introducing microalgae into the RAS by immobilizing the cells in spherical gels could be a suitable way to improve water quality and fish production. The use of small gels containing algae would increase the surface area for absorption and increase the uptake rate. Furthermore, this immobilization technique will reduce the risks of contamination of the biofilter by microalgae and reduce the risk of clogging pipes in RAS.

Immobilization or entrapment of microalgal cells in spherical gels is used in the wastewater industry to ease the harvesting method (de la Noüe and Proulx 1988, Travieso et al. 1992). To date, about 30 species of microalgae have been studied using this immobilization technique for removing nitrogen and phosphorus in wastewater (de-Bashan \& Bashan 2010). Of the studied species, $75 \%$ were green microalgae, e.g. Chlorella, Scenedesmus, and Botryococcus spp., $20 \%$ were cyanobacteria, e.g. Anabaena and Spirulina spp., and the remaining $5 \%$ were brown microalgae, e.g. diatoms and euglenoid microalgae. Most of the species tested were planktonic microalgae. Reports on the use of epiphytic microalgae are few, not only in immobilization technique studies but also in wastewater treatment. According to de Paula Silva et al. (2008), one reason to explain why epiphytic microalgae were less studied might be because their economic value is unclear. However, the application of epiphytes such as Cladophora coelothrix Kützing and Chaetomorpha indica Kützing in Northern Queensland, Australia, proved that epiphytic microalgae were effective in removing inorganic nitrogen and phosphate from aquaculture waste (de Paula Silva et al. 2008). In the case of the RAS, epiphytic microalgae on substrates posed a lesser risk of clogging and could be easily removed from the systems in situ.

Previous studies reported that the epiphytic green microalga Stigeoclonium tenue Kütz. can be an indicator of highly contaminated water because this species has a high tolerance to heavy metals (PawlikSkowronska 2001). This implies that Stigeoclonium sp. can be potentially used to remove nutrients from the wastewater. Moreover, this species also has a high lipid content, making it a potential food or biofuel source (Praveenkumar et al. 2012).

Motivated by these benefits, we explored the suitability of culturing Stigeoclonium nanum immobilized in alginate beads and its inorganic nitrogen uptake. First we compared the growth and ammonium uptake by $S$. nanum in free suspension to that of $S$. nanum immobilized in alginate. Then we analyzed the rates of ammonium and nitrate uptake in immobilized $S$. nanum beads.

\section{MATERIALS AND METHODS}

\section{Microalgal culture maintenance}

Stigeoclonium nanum was isolated from a tilapia grow-out tank in the Aquatic Animal Health Unit, Faculty of Veterinary Medicine, Universiti Putra Malaysia. The pure culture was maintained in Bold's basal medium, maintained in $24 \mathrm{~h}$ light (55-60 $\mu \mathrm{mol}$ photons $\mathrm{m}^{-2} \mathrm{~s}^{-1}$ ) at $26 \pm 0.5^{\circ} \mathrm{C}$ and $\mathrm{a} \mathrm{pH}$ of $8.0 \pm 0.5$. Low light conditions are suitable for this epiphytic species, which is thus a candidate for RAS operated under relatively low light conditions. In nature, $S$. nanum has an affinity for low light and is commonly found on substrates in highly shaded forest streams (Steinman 1992).

For immobilization of $S$. nanum, a pure culture of $S$. nanum was inoculated in $3 \%$ sodium alginate solution. Round beads approximately $3 \mathrm{~mm}$ in diameter 
were produced in $2 \%$ calcium chloride solidification solution as an ionic cross-linking agent. One $\mathrm{ml}$ of sodium alginate solution produced $30 \pm 2.8$ beads weighing $0.952 \pm 0.03 \mathrm{~g}$. Before the beads were used, they were acclimatized in the culture water (before the addition of ammonium and nitrate) at the experimental light and temperature for $3 \mathrm{~h}$.

\section{Experimental design and procedures}

Two experiments were carried out to illustrate the effects of immobilized microalgae in alginates in a RAS system. The first experiment compared growth and total ammonia nitrogen (TAN) uptake by freeliving and immobilized microalgae. The negative control for the free-living treatment contained only culture water, while the negative control for immobilized microalgae contained alginate beads without microalgae.

In the second experiment, a $2 \times 2$ factorial design was used to determine the uptake of TAN and nitrate-nitrogen $\left(\mathrm{NO}_{3}-\mathrm{N}\right)$. The treatments were (1) TAN concentration $=0 \mathrm{mg} \mathrm{l}^{-1}, \mathrm{NO}_{3}-\mathrm{N}$ concentration $=$ $0 \mathrm{mg} \mathrm{l}^{-1}$ (TONO); (2) TAN $=5 \mathrm{mg} \mathrm{l}^{-1}, \mathrm{NO}_{3}-\mathrm{N}=0 \mathrm{mg} \mathrm{l}^{-1}$ (T5N0); (3) $\mathrm{TAN}=0 \mathrm{mg} \mathrm{l}^{-1}, \mathrm{NO}_{3}-\mathrm{N}=10 \mathrm{mg} \mathrm{l}^{-1}$ (T0N10); and (4) TAN $=5 \mathrm{mg} \mathrm{l}^{-1}, \mathrm{NO}_{3}-\mathrm{N}=10 \mathrm{mg} \mathrm{l}^{-1}$ (T5N10). Experiments were conducted with 3 replicates each.

The experiments were carried out under 55-60 $\mu \mathrm{mol}$ photons $\mathrm{m}^{-2} \mathrm{~s}^{-1}$ light at $26 \pm 0.5^{\circ} \mathrm{C}$ and a $\mathrm{pH}$ of $8.0 \pm$ 0.5 under $24 \mathrm{~h}$ of light per day. The cultures were aerated by continuous bubbling of sterile air. The culture medium was lake water that was filtered and autoclaved before use.

\section{Expt 1}

An initial concentration of $0.5 \mathrm{~g} \mathrm{l}^{-1} S$. nanum (wet weight) was inoculated in $1200 \mathrm{ml}$ medium as freeliving $S$. nanum. In the immobilized-beads treatment, $200 \mathrm{~g}$ microalgae beads were used which also contained $0.5 \mathrm{~g} \mathrm{l}^{-1} S$. nanum.

A microalgal culture medium containing $2.0 \mathrm{mg} \mathrm{l}^{-1}$ of TAN was prepared using an ammonium chloride stock solution (3.819 $\mathrm{g} \mathrm{NH}_{4} \mathrm{Cl}$ in $1 \mathrm{l}$ of ultrapure water; $1 \mathrm{ml}=1 \mathrm{mg} \mathrm{N}$ ). The TAN level was determined on alternate days for $20 \mathrm{~d}$. Every time the TAN level reached $0 \mathrm{mg} \mathrm{l}^{-1}$, the stock solution was added to raise the concentration to $2.0 \mathrm{mg} \mathrm{TAN}^{-1}$. Beads $(6 \mathrm{~g})$ from the immobilized microalgae treatments and $10 \mathrm{ml}$ from the free-living treatments were sampled every $4 \mathrm{~d}$ to determine chlorophyll a $(\mathrm{chl} a)$ content and microalgal biomass.

\section{Expt 2}

In Expt 2, the same experimental conditions as in Expt 1 were applied. The TAN stock solution was prepared as in Expt 1. $\mathrm{NO}_{3}-\mathrm{N}$ stock solution was prepared using potassium nitrate $\left(0.7218 \mathrm{~g} \mathrm{KNO}_{3}\right.$ in $1 \mathrm{l}$ of ultrapure water; $1 \mathrm{ml}=100 \mu \mathrm{g} \mathrm{NO} \mathrm{N}_{3}-\mathrm{N}$ ). Concentrations of TAN and $\mathrm{NO}_{3}-\mathrm{N}$ in culture water were measured daily. The experiment lasted for $6 \mathrm{~d}$.

\section{Algal growth rate and total ammonia nitrogen and nitrate measurement}

For microalgal biomass ( $g$ dry weight $1^{-1}$ ) determination in the bead treatment, $3 \mathrm{~g}$ of beads were solubilized by immersing them in $10 \mathrm{ml}$ of $0.5 \mathrm{~mol}$ trisodium citrate solution ( $\mathrm{pH}$ 6.5). Microalgal cells were then filtered on prewashed GF/F Whatman filter paper and dried overnight at $60^{\circ} \mathrm{C}$. For free-living microalgae, $5 \mathrm{ml}$ of culture medium were filtered. The mass difference between prewashed filter paper and filter paper with oven-dried microalgae was recorded as the biomass ( $g$ ) of the microalgae. The specific growth rate $\left(\mathrm{d}^{-1}\right)$ was calculated from the exponential growth phase of the microalgae (ln $W_{1}-$ ln $\left.W_{0}\right) / \Delta t_{\text {; }}$ where $W_{0}$ is biomass (weight) of microalgae at the beginning of the time interval, $W_{1}$ is the biomass at the end of the time interval, and $\Delta t$ is the length of the time interval $\left(T_{1}-T_{0}\right)$. The growths of free-living and immobilized microalgae were fitted with a logistic growth model using the non-linear regression function in SPSS. The formula for the logistic growth model is

$$
P=\frac{K}{1+A \mathrm{e}^{(-r T)}}
$$

where $P$ is the population of microalgae, $K$ is the carrying capacity, $A$ is a constant, $r$ is the intrinsic growth rate, and $T$ is time in days.

Chl a was determined following the standard method for the examination of water and wastewater (APHA 1999). Beads (3 g) were solubilized in 0.5 molar trisodium citrate at room temperature. Microalgal cells in the solubilized beads were then retained on GF/F Whatman filter paper using a filtration unit attached to a vacuum pump. After filtration, chl a pigment was extracted by mechanical disruption in $10 \mathrm{ml}$ of a $90 \%$ acetone solution using a tissue 
grinder until it was converted to the slurry. The solution was allowed to stand overnight at $4^{\circ} \mathrm{C}$. The clarified extract was then left until it reached room temperature. Then, $3 \mathrm{ml}$ of extract were transferred to a $1 \mathrm{ml}$ cuvette and absorbance was read at wavelengths of 750 and $664 \mathrm{~nm}$ (before acidification) and 750 and $665 \mathrm{~nm}$ (after acidification) with a spectrophotometer (UV-Vis Spectrophotometer, UV-1700 series, Shimadzu). Chl a is expressed in $\mu \mathrm{g} \mathrm{l}^{-1}$.

The pigments were calculated using the equation:

$$
\text { Chlorophyll a }\left(\mu \mathrm{g} \mathrm{l}^{-1}\right)=\frac{26.7\left(664_{\mathrm{b}}-665_{\mathrm{a}}\right) \times V_{1}}{V_{2} \times L}
$$

where 26.7 is the absorbance coefficient used for chl $a$ at $664 \mathrm{~nm}$ (11.00) multiplied by the ratio expressing the correction for acidification (2.43); $V_{1}$ is the volume of extract (ml), $V_{2}$ is the volume of sample (l), $L$ is the light path length or width of the cuvette $(\mathrm{cm})$, and $664_{b}, 665_{a}$ are the absorbances of $90 \%$ acetone extract before and after acidification, respectively.

The TAN and $\mathrm{NO}_{3}-\mathrm{N}$ concentrations $\left(\mathrm{mg} \mathrm{l}^{-1}\right)$ were measured by ion chromatography. All chromatographic analyses were performed at room temperature using a Metrohm model 882 Compact IC Plus with suppressor module. Data were collected using a data acquisition system interfaced to a computer running MagIC Net 1.1 software (Metrohm).

In this study, we defined removal of TAN and $\mathrm{NO}_{3}-\mathrm{N}$ by microalgae as their disappearance from the culture medium (Dortch 1982).

\section{Statistical analysis}

A 1-way ANOVA was used in the first trial, with culture method (presence/absence of alginate beads) as the main factor and sampling day as the repeated measure. In the second experiment, addition/no addition of TAN and $\mathrm{NO}_{3}$ were the main factors, and sampling day was included as a repeated-measure factor. The statistical software SPSS (IBM SPSS Statistics, version 20) was used for the analyses.

\section{RESULTS}

\section{Expt 1}

Algal growth in free-living and immobilized microalgal beads (Stigeoclonium nanum)

A significant difference in algal biomass and chl a content was observed between free-living and
Table 1. Mean \pm SE of biomass, chlorophyll a content, and specific growth rate (SGR) of free-living and immobilized microalgae Stigeoclonium nanum in Expt 1. An initial concentration of $0.5 \mathrm{~g} \mathrm{l}^{-1} S$. nanum (wet weight) was inoculated in $1200 \mathrm{ml}$ medium as free-living algae. In the immobilizedbeads treatment, $200 \mathrm{~g}$ microalgae beads were used which also contained $0.5 \mathrm{~g} \mathrm{l}^{-1} S$. nanum. Sampling occurred every $4 \mathrm{~d}$ for $20 \mathrm{~d}$. Asterisks indicate significant differences between the methods; ${ }^{* * *} \mathrm{p}<0.001,{ }^{*} \mathrm{p}<0.05$. DW: dry weight

\begin{tabular}{|lccc|}
\hline Culture method & $\begin{array}{c}\text { Biomass } \\
\left(\mathrm{g} \mathrm{DW} \mathrm{l} \mathrm{l}^{-1}\right)\end{array}$ & $\begin{array}{c}\mathrm{Chl} a \\
\left(\mu \mathrm{g} \mathrm{l}^{-1}\right)\end{array}$ & $\begin{array}{c}\mathrm{SGR} \\
\left(\mathrm{d}^{-1}\right)\end{array}$ \\
\hline $\begin{array}{l}\text { Free-living } \\
\text { microalgae }\end{array}$ & $0.10 \pm 0.01$ & $300 \pm 35$ & $0.23 \pm 0.06$ \\
$\begin{array}{l}\text { Immobilized } \\
\text { microalgae }\end{array}$ & $0.23 \pm 0.01$ & $3240 \pm 43$ & $0.40 \pm 0.06$ \\
$\begin{array}{l}\text { Significant } \\
\text { difference }\end{array}$ & $* * *$ & $* * *$ & $*$ \\
\hline
\end{tabular}

immobilized microalgae throughout the experiment $(\mathrm{p}<0.001$; Table 1$)$. The specific growth rate of the immobilized microalgae was significantly higher than that of the free-living microalgae $(p<0.05)$. The growth curve (Fig. 1) showed that the lag phases for immobilized and free-living microalgae lasted until Day 4. Growth rates were exponential from Day 4 through Day 12 for immobilized microalgae and from Day 4 through Day 8 for free-living microalgae. The logistic growth model could explain $73 \%$ of the growth for immobilized microalgae and $71.4 \%$ for

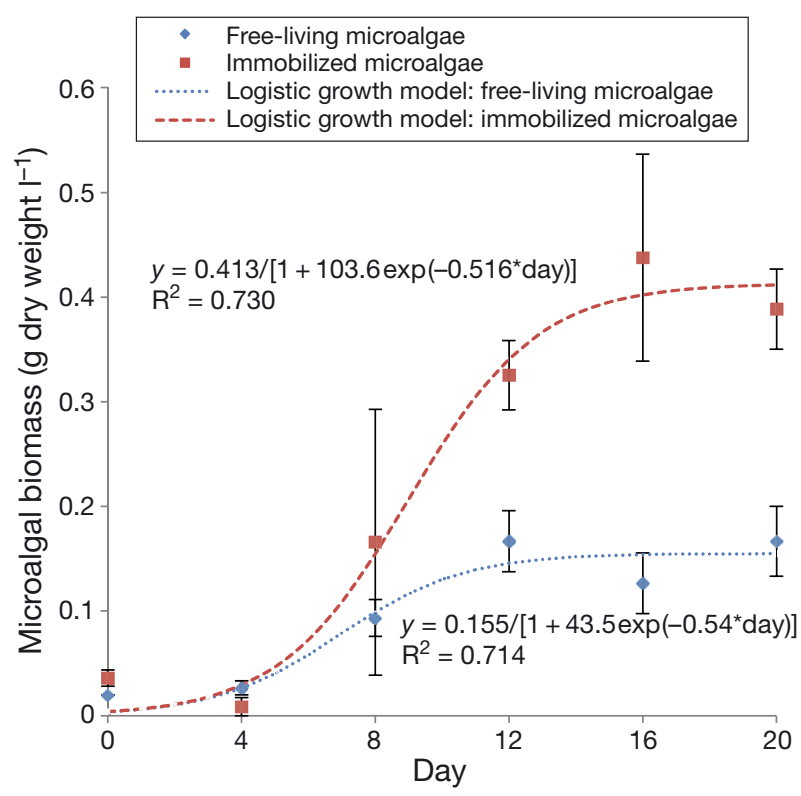

Fig. 1. Biomass ( $g$ dry weight $\mathrm{l}^{-1}$, mean $\pm \mathrm{SD}$ ) of free-living and immobilized microalgae Stigeoclonium nanum. Dotted lines indicate the logistic growth regression curves obtained in this study 


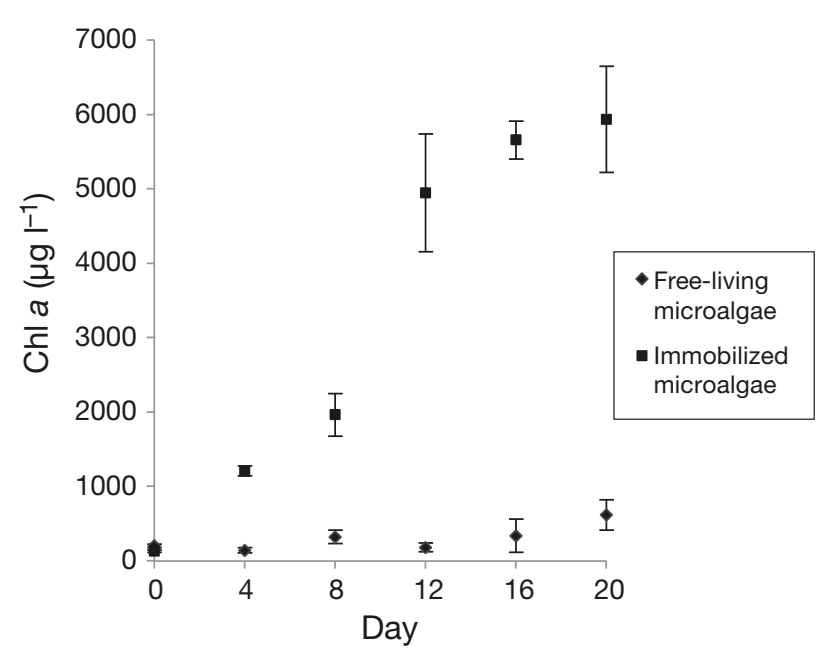

Fig. 2. Chlorophyll a $\left(\mu g \mathrm{l}^{-1}\right)$ content (mean $\left.\pm \mathrm{SD}\right)$ in freeliving and immobilized microalgae Stigeoclonium nanum

free-living microalgae. The chl a content in immobilized microalgae was 10 times greater than in freeliving microalgae (Fig. 2). Chl a content in immobilized microalgae increased until Day 20 from 140 to $5900 \mu \mathrm{g} \mathrm{l}^{-1}$, whereas chl a content in free-living microalgae increased from 200 to $620 \mathrm{\mu g} \mathrm{l}^{-1}$.

TAN removal by free-living and immobilized microalgae

The slope of the graph in Fig. 3 represents the TAN removal rate $\left(\mathrm{mg} \mathrm{l}^{-1} \mathrm{~d}^{-1}\right)$. A higher TAN removal rate was achieved by immobilized microalgae $\left(0.68 \mathrm{mg} \mathrm{l}^{-1}\right.$ $\left.\mathrm{d}^{-1}\right)$ than by free-living microalgae $\left(0.38 \mathrm{mg} \mathrm{l}^{-1} \mathrm{~d}^{-1}\right.$; $\mathrm{p}<0.05$ ).

\section{Expt 2}

The $\mathrm{NO}_{3}-\mathrm{N}$ removal rate in treatment T0N10 was $0.53 \mathrm{mg} \mathrm{NO}-\mathrm{N} \mathrm{l}^{-1} \mathrm{~d}^{-1}\left(\mathrm{R}^{2}=0.97\right)$ and negligible in treatment T5N10 (Fig. 4A). The removal rate which was shown by the negative slope was $0.51 \mathrm{mg}$ TAN $\mathrm{l}^{-1} \mathrm{~d}^{-1}\left(\mathrm{R}^{2}=0.86\right)$ in treatment T5N0 and $0.67 \mathrm{mg}$ TAN $\mathrm{l}^{-1} \mathrm{~d}^{-1}\left(\mathrm{R}^{2}=0.92\right)$ in treatment T5N10 (Fig. 4B). T5N10 had higher TAN removal at the end of the study $(83 \%)$ when compared to T5N0 $(70 \%)$. The interaction between TAN and $\mathrm{NO}_{3}-\mathrm{N}$ was significant (Table 2).

\section{DISCUSSION}

\section{Expt 1}

Algal growth in free-living and immobilized microalgal beads

We found that immobilized Stigeoclonium nanum had 2.3 times greater biomass and 10 times greater $\mathrm{chl}$ a content than the free-living $S$. nanum. At the beginning of this study, $S$. nanum was expected to grow well in low light, but growth was similarly low as in other microalgal species under the same light condi-
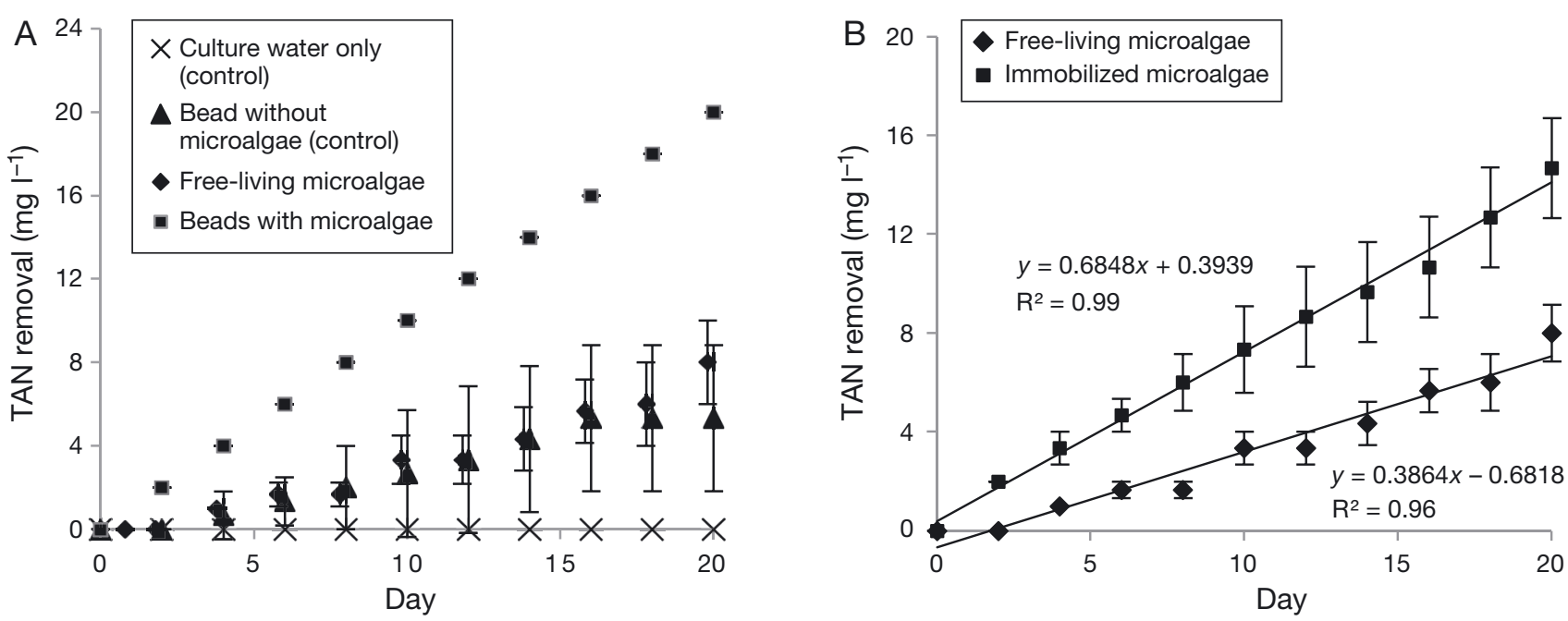

Fig. 3. (A) Mean $( \pm \mathrm{SD})$ values of cumulative total ammonia nitrogen (TAN) removal $\left(\mathrm{mg} \mathrm{l}^{-1}\right)$ in culture water only (control), in beads without microalgae Stigeoclonium nanum (control), in free-living microalgae, and in beads with immobilized microalgae during the experiment. (B) Mean $( \pm \mathrm{SD})$ values of cumulative TAN removal $\left(\mathrm{mg} \mathrm{l}^{-1}\right)$ in free-living and immobilized microalgae (= beads with microalgae - beads without microalgae) 


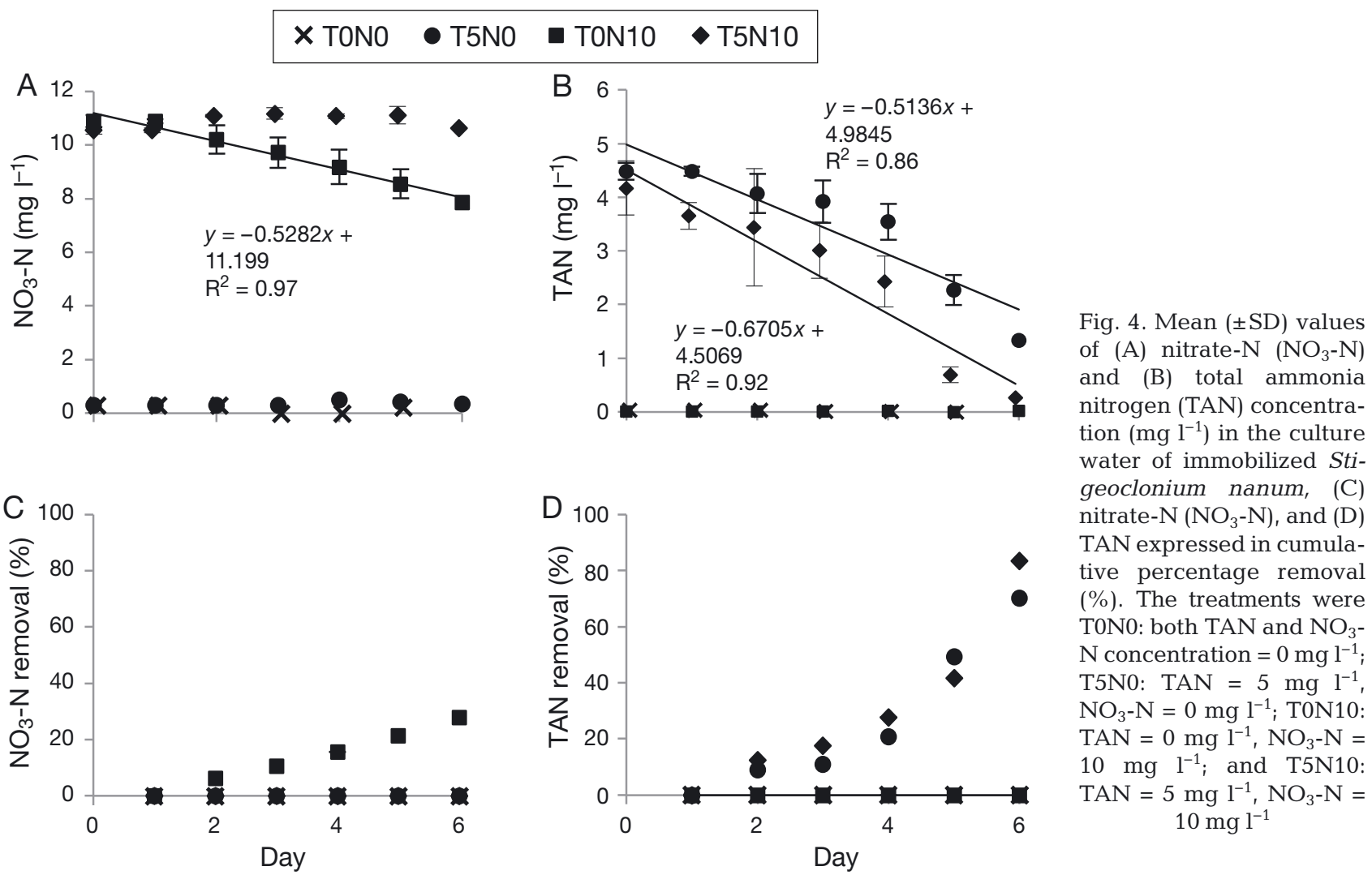

tions (Imaizumi et al. 2014). For comparison, Imaizumi et al. (2014) reported that Chlorella zofingiensis showed a high growth rate of $0.7 \mathrm{~d}^{-1}$ at $1000 \mu \mathrm{mol}$ photons $\mathrm{m}^{-2} \mathrm{~s}^{-1}$, but the growth rate decreased to $0.4 \mathrm{~d}^{-1}$ at $75 \mu \mathrm{mol}$ photons $\mathrm{m}^{-2} \mathrm{~s}^{-1}$. That study reported the maximum production of $C$. zofingiensis cultured under non-limiting nutrient and carbon dioxide conditions. The growth rate of $S$. nanum in our study was comparable to that of C. zofingiensis in Imaizumi et al. (2014) under low light conditions. Microalgal production is a critical parameter for the uptake of ammonium, so it may be that if the beads were cultured in high light intensity, the growth rate would increase, and ammonium uptake would also increase.

This finding was similar to other studies which reported that immobilization did not negatively affect growth of the microalgae Synechococcus elongatus
(Aguilar-May \& Sánchez-Saavedra 2009), Chaetoceros gracilis, Thalassiosira pseudonana, Phaeodactylum tricornutum (Moreno-Garrido et al. 2005), and Dunaliella salina (Thakur \& Kumar 1999). One study with Chlorella vulgaris immobilized in carrageenan showed a 2 times higher chlorophyll synthesis rate when compared to free-living microalgae (Lau et al. 1998). In addition to better growth, immobilized Botryococcus braunii and B. protuberans produced $8 \%$ more chlorophyll, $15 \%$ more carotenoids, $15 \%$ higher dry weight, and $7 \%$ more lipid during stationary growth phases in comparison to free-living cells. In addition, photosynthesis in both species was enhanced and senescence was significantly delayed under immobilized conditions (Singh 2003). In other studies, chlorophyll content of harvested immobilized $S$. elongatus was $50 \%$ higher than that of free

Table 2. Two-way repeated-measures ANOVA of total ammonia nitrogen (TAN) and nitrate $\left(\mathrm{NO}_{3}\right.$ - $\left.\mathrm{N}\right)$ concentration (mg $\mathrm{l}^{-1}$ ) in the culture water of immobilized Stigeoclonium nanum, comparing between factors $\mathrm{TAN}, \mathrm{NO}_{3}$, and day. Values shown are $p$-values

\begin{tabular}{|lccccccc|}
\hline Parameter & $\mathrm{TAN}$ & $\mathrm{NO}_{3}$ & $\mathrm{TAN} \times \mathrm{NO}_{3}$ & Day & Day $\times \mathrm{TAN}$ & Day $\times \mathrm{NO}_{3}$ & Day $\times \mathrm{TAN}^{2} \mathrm{NO}_{3}$ \\
\hline TAN & $<0.0001$ & 0.024 & 0.026 & $<0.0001$ & $<0.0001$ & 0.982 & 0.978 \\
$\mathrm{NO}_{3}-\mathrm{N}$ & 0.002 & $<0.0001$ & 0.010 & 0.002 & 0.003 & 0.003 & 0.055 \\
\hline
\end{tabular}


cells (Aguilar-May \& Sánchez-Saavedra 2009). Scenedesmus sp. immobilized in chitosan was found to have 2.6 higher growth than the free cell cultures (Fierro et al. 2008).

Not all microalgae grow well under immobilized conditions, e.g. Skeletonema costatum (Moreno-Garrido et al. 2005), Heterocapsa sp., and dinoflagellates (Moreno-Garrido 2008). Immobilization changes the nature of algal growth. When microalgae are confined in a limited space, interactions occurring between the immobilization matrix and the cell wall affected algal metabolism (Moreno-Garrido 2008). Characteristics of alginate such as alginate chemistry, mechanical and chemical stability, pore size, and pore distribution influenced algal growth (Thu et al. 1996). Alginate consists of a family of copolymers which contain 1-4-linked $\beta$-D-mannuronic acid and $\alpha$-L-guluronic acid in different proportions and sequences (Martinsen et al. 1989). High content of guluronic acid contributes to high gel strength, volume stability, and large pore size which permits high permeability. These characteristics are advantageous for immobilization of living cells (Martinsen et al. 1989, Thu et al. 1996). Additionally, alginate did not cause extreme physical-chemical changes during the immobilization process, which is an advantage of using alginate and makes it one of the most used polymers for cell immobilization (Moreno-Garrido 2008). The carrying capacity $(K)$ and intrinsic growth rate $(r)$ calculated with the logistic growth model were higher for immobilized microalgae than for free-living microalgae. Carrying capacity for microalgal growth is normally determined by nutrient content and environmental factors in the culture, such as light and carbon dioxide. In this experiment, in which nutrient and environmental factors were kept the same between treatments, the higher carrying capacity was due to immobilization in alginate. Some microalgae attached on the flask wall during the early growth phase of $S$. nanum in free suspension. With increasing biomass, detached microalgae formed floating mats at the surface. In the immobilized microalgae treatment, the beads must have acted as a substrate for the microalgae to grow and contributed to the carrying capacity in this treatment. This might be the explanation why $S$. nanum was able to grow well in immobilization beads. At the end of the experiment, the microalgae protruded out of the beads, overgrowing the bead's surface, but did not switch to free-living conditions. This situation could be beneficial to ease the harvesting even in those beads in which microalgae grew out from the spherical beads.
Ammonium removal by free-living microalgae and immobilized microalgae

In immobilized microalgae culture, ammonium removal is defined as the adsorption of the nutrient from the external medium into the alginate and the uptake of the nutrient from the alginate into the microalgal cells (Tam \& Wong 2000). Ammonium removal in the culture media might also be caused by nitrification or by ammonia volatilization. Therefore, in this study, a control treatment which contained only culture water was used to account for nitrification and volatilization in the water column. The blank bead control treatment was used to account for nitrification, volatilization of ammonia, and adsorption of ammonium by the alginate. After the control treatment was taken into account, this study showed that microalgal cells in beads removed $46 \%$ more ammonium than microalgal cells in free-living culture. This result was in accordance with the higher growth that was achieved in the microalgae beads. Similarly, Lau et al. (1997) suggested that ammonium consumption was dependent on the metabolic activity of the algal cells even in an immobilized state. In that study, Lau et al. (1997) compared the growth of Chlorella vulgaris in free suspension, and immobilized in alginate and carrageenan. Higher metabolic activity was indicated by the higher chlorophyll, which was correlated with the higher uptake of nitrogen and phosphate in the immobilized beads than in the free-living C. vulgaris.

In our study, immobilized $S$. nanum consumed $19.54 \pm 0 \mathrm{mg}$ ammonium per $1200 \mathrm{ml}$ flask on the final day of the trial. Free-floating $S$. nanum only used $40 \%(7.84 \pm 2.61 \mathrm{mg})$, and empty beads used $35 \%(7.02 \pm 2.34 \mathrm{mg})$ of the total amount that immobilized $S$. nanum had used. This trend was similar to the result of a previous study where blank chitosan beads were responsible for removing up to $20 \%$ nitrate and $60 \%$ phosphate from the culture medium (Fierro et al. 2008). Uptake by the gel matrices could be explained by the fact that polyanionicity of the polysaccharide gels could bind with ammonium in a saturable and mass balance manner (Lau et al. 1997).

In a review by de-Bashan \& Bashan (2010), higher ammonium uptake was observed in most immobilized microalgae than suspended microalgae. When C. vulgaris immobilized in carrageenan and alginate were used to treat primary domestic wastewater, over $95 \%$ of $\mathrm{NH}_{4}{ }^{+}-\mathrm{N}$ was removed in $3 \mathrm{~d}$. However, only $50 \%$ of $\mathrm{NH}_{4}{ }^{+}-\mathrm{N}$ was removed by suspended microalgae during the same time period (Lau et al. 1997). 
De la Noüe \& Proulx (1988) found that chitosanPhormidium sp. aggregates were capable of removing $95 \%$ of inorganic nitrogen from a secondary effluent within 4 to $6 \mathrm{~h}$. Meanwhile, ammonium uptake by immobilized Dunaliella salina was $17 \mathrm{mg}$ $\mathrm{l}^{-1} \mathrm{~h}^{-1}$ compared to free-living $D$. salina, which only had $14.5 \mathrm{mg} \mathrm{l}^{-1} \mathrm{~h}^{-1}$ (Thakur \& Kumar 1999).

\section{Expt 2}

Selective removal of ammonium and nitrate ions can be defined as the preference of microalgae for ammonium ions and inhibition of nitrate uptake in the presence of the former (Dortch 1990). The latter study concluded that the uptake competition between nitrate and ammonium ions is complex and influenced by environmental conditions.

Our study showed that nitrate removal occurred in treatment T0N10 but not in treatment T5N10, indicating that immobilized $S$. nanum preferred ammonium above nitrate as the nitrogen source. The significant interaction found in this study might indicate that the presence of ammonium influenced the removal of nitrate. Past studies reported that some microalgae preferred ammonium over nitrate as the nitrogen source (Dortch 1990, Raven et al. 1992, Domingues et al. 2011, Parker et al. 2012). Dortch (1990) listed microalgae which prefer ammonium, including Chlamydomonas pulsatilla, Phaeodactylum tricornutum, and Chaetoceros gracilis. A more recent study also showed that Nannochloropsis sp. prefers ammonium over nitrate (Hii et al. 2011). In contrast to this, another study found that Nannochloropsis oculata and Chlorella vulgaris preferred nitrate over ammonium (Podevin et al. 2015). However, we found no specific report on $S$. nanum. Domingues et al. (2011) reported that a preference for ammonium was mainly observed in green microalgae and cyanobacteria but not in diatoms and dinoflagellates.

When both ammonium and nitrate are present, ammonium will be used first by the microalgae and inhibit nitrate uptake (Ohmori et al. 1977, Serra et al. 1978, Córdoba et al. 1986, Dortch 1990, Hii et al. 2011). A possible explanation is that when ammonium enters the cell at a high rate, strong membrane depolarization occurs which blocks the anion/ $\mathrm{H}^{+}$cotransport (Flynn 1991). On the other hand, during ammonium assimilation, glutamine synthetase (GS), an enzyme which is involved in ammonium metabolism in microalgal cells, is active. GS competes with the nitrate uptake systems for adenosine triphosphate.
This competition may cause inhibition of nitrate uptake (Ohmori et al. 1977).

Knowing the removal rate of ammonium and nitrate is important to be able to predict the time needed to remove these compounds from the RAS. In this study, the removal rate, as predicted by linear regression in Fig. 4B, showed that the ammonium removal rate was higher in cultures where both ammonium and nitrate were present than in a culture where only ammonium was present. Therefore, a higher removal percentage of ammonium was achieved when both ammonium and nitrate were present. Raven et al. (1992) mentioned a situation where a higher growth rate was achieved when both ammonium and nitrate were available compared to when only ammonium or nitrate was available; however, this situation did not occur frequently. Therefore, in our study, we speculated that the higher growth rate could link to higher ammonium uptake when both nutrients were available. However, a difference in growth was not observed in our study (data not shown), probably due to the short experimental period. Until further research is done, this finding remains inconclusive.

Finally, our results suggest that immobilized $S$. nanum is a suitable candidate to be incorporated into a system in which ammonia is produced daily, as in aquaculture systems; however, if $S$. nanum is incorporated for nitrate removal in RAS, an $S$. nanum reactor should be placed after the nitrification reactor when all ammonia has been converted to nitrate, in order to reduce the inhibition of nitrate uptake by the ammonium. Furthermore, the flow into an $S$. nanum reactor should be regulated independently from the nitrifying reactor to allow for a higher retention time and thus a more efficient nitrate uptake by $S$. nanum. Future studies should investigate how the stability of the beads is influenced by aquaculture water conditions. Stability in this case is related to the time before disruption of the alginate. The information is important to predict the life span of the beads. In this way, the time to harvest and bead replacement will be known, allowing for continuous nitrogen removal by the immobilized microalgae in RAS.

Acknowledgements. This work was supported by the Ministry of Higher Education, Malaysia (Skim Latihan Akademik IPTA) and the International Foundation for Science (grant number A/5348-1). We thank Profesor Dr. Mohamed Shariff Mohamed Din, Dr. Sanjoy Banerjee, and Maya Erna Natnan for their support during the experiment. 


\section{LITERATURE CITED}

Abdel-Raouf N, Al-Homaidan AA, Ibraheem IBM (2012) Microalgae and wastewater treatment. Saudi J Biol Sci 19:257-275

Aguilar-May B, Sánchez-Saavedra MP (2009) Growth and removal of nitrogen and phosphorus by free-living and chitosan-immobilized cells of the marine cyanobacterium Synechococcus elongatus. J Appl Phycol 21:353-360

APHA (American Public Health Association) (1999) Standard method for the examination of water and wastewater, $20^{\text {th }}$ edn. American Public Health Association, American Water Work Association, Water Environment Federation, Washington, DC

* Córdoba F, Cárdenas J, Fernández E (1986) Kinetic characterization of nitrite uptake and reduction by Chlamydomonas reinhardtii. Plant Physiol 82:904-908

Davidson J, Good C, Welsh C, Summerfelt ST (2014) Comparing the effects of high vs. low nitrate on the health, performance, and welfare of juvenile rainbow trout Oncorhynchus mykiss within water recirculating aquaculture systems. Aquacult Eng 59:30-40

de-Bashan LE, Bashan Y (2010) Immobilized microalgae for removing pollutants: review of practical aspects. Bioresour Technol 101:1611-1627

de la Noüe J, Proulx D (1988) Biological tertiary treatment of urban wastewaters with chitosan-immobilized Phormidium. Appl Microbiol Biotechnol 29:292-297

de Paula Silva PH, McBride S, de Nys R, Paul NA (2008) Integrating filamentous 'green tide' algae into tropical pond-based aquaculture. Aquaculture 284:74-80

* Domingues RB, Barbosa AB, Sommer U, Galvão HM (2011) Ammonium, nitrate and phytoplankton interactions in a freshwater tidal estuarine zone: potential effects of cultural eutrophication. Aquat Sci 73:331-343

Dortch Q (1982) Effect of growth conditions on accumulation of internal pools of nitrate, ammonium, amino acids, and protein in three marine diatoms. J Exp Mar Biol Ecol 61: 243-264

*Dortch Q (1990) The interaction between ammonium and nitrate uptake in phyplankton. Mar Ecol Prog Ser 61: 183-201

Ebeling JM, Timmons MB, Bisogni JJ (2006) Engineering analysis of the stoichiometry of photoautotrophic, autotrophic, and heterotrophic removal of ammonia-nitrogen in aquaculture systems. Aquaculture 257:346-358

Fierro S, del Pilar Sánchez-Saavedra M, Copalcúa C (2008) Nitrate and phosphate removal by chitosan immobilized Scenedesmus. Bioresour Technol 99:1274-1279

Flynn KJ (1991) Algal carbon-nitrogen metabolism: a biochemical basis for modelling the interactions between nitrate and ammonium uptake. J Plankton Res 13:373-387

Hii YS, Soo CL, Chuah TS, Mohd-Azmi A, Abol-Munafi AB (2011) Interactive effect of ammonia and nitrate on the nitrogen uptake by Nannochloropsis sp. J Sustain Sci Manag 6:60-68

Imaizumi Y, Nagao N, Yusoff FM, Taguchi S, Toda T (2014) Estimation of optimum specific light intensity per cell on a high-cell-density continuous culture of Chlorella zofingiensis not limited by nutrients or $\mathrm{CO}_{2}$. Bioresour Technol 162:53-59

Lau PS, Tam NFY, Wong YS (1997) Wastewater nutrients (N and $\mathrm{P}$ ) removal by carrageenan and alginate immobilized Chlorella vulgaris. Environ Technol 18:945-951

Kau PS, Tam NFY, Wong YS (1998) Effect of carrageenan immobilization on the physiological activities of Chlorella vulgaris. Bioresour Technol 63:115-121

Martins CIM, Pistrin MG, Ende SSW, Eding EH, Verreth JAJ (2009) The accumulation of substances in Recirculating Aquaculture Systems (RAS) affects embryonic and larval development in common carp Cyprinus carpio. Aquaculture 291:65-73

* Martins CIM, Eding EH, Verdegem MCJ, Heinsbroek LTN and others (2010) New developments in recirculating aquaculture systems in Europe: a perspective on environmental sustainability. Aquacult Eng 43:83-93

*Martinsen A, Skjåk-Bræk G, Smidsrød O (1989) Alginate as immobilization material: I. Correlation between chemical and physical properties of alginate gel beads. Biotechnol Bioeng 33:79-89

* Moreno-Garrido I (2008) Microalgae immobilization: current techniques and uses. Bioresour Technol 99:3949-3964

*Moreno-Garrido I, Campana O, Lubián LM, Blasco J (2005) Calcium alginate immobilized marine microalgae: experiments on growth and short-term heavy metal accumulation. Mar Pollut Bull 51:823-829

Needoba JA, Sigman DM, Harrison PJ (2004) The mechanism of isotope fractionation during algal nitrate assimilation as illuminated by the ${ }^{15} \mathrm{~N} /{ }^{14} \mathrm{~N}$ of intracellular nitrate. J Phycol 40:517-522

* Ohmori M, Ohmori K, Strotmann H (1977) Inhibition of nitrate uptake by ammonia in a blue-green alga, Anabaena cylindrica. Arch Microbiol 114:225-229

* Parker AE, Dugdale RC, Wilkerson FP (2012) Elevated ammonium concentrations from wastewater discharge depress primary productivity in the Sacramento River and the Northern San Francisco Estuary. Mar Pollut Bull 64:574-586

* Pawlik-Skowronska B (2001) Phytochelatin production in freshwater algae Stigeoclonium in response to heavy metals contained in mining water; effects of some environmental factors. Aquat Toxicol 52:241-249

* Perez-Garcia O, Escalante FME, de-Bashan LE, Bashan Y (2011) Heterotrophic cultures of microalgae: metabolism and potential products. Water Res 45:11-36

* Piedrahita RH (2003) Reducing the potential environmental impact of tank aquaculture effluents through intensification and recirculation. Aquaculture 226:35-44

*Podevin M, De Francisci D, Holdt SL, Angelidaki I (2015) Effect of nitrogen source and acclimatization on specific growth rates of microalgae determined by a highthroughput in vivo microplate autofluorescence method. J Appl Phycol 27:1415-1423

* Praveenkumar R, Johncy K, MubarakAli D, Vijayan D, Thajuddin N, Gunasekaran M (2012) Demonstration of increased lipid accumulation potential of Stigeoclonium sp., Kütz. BUM11007 under nitrogen starved regime: a new source of lipids for biodiesel production. J Biobased Mater Bioenergy 6:209-213

* Raven JA, Wollenweber B, Handley LL (1992) A comparison of ammonium and nitrate as nitrogen sources for photolithotrophs. New Phytol 121:19-32

* Serra JL, Llama MJ, Cadenas E (1978) Nitrate ulitization by the diatom Skeletonema costatum. Plant Physiol 62: 991-994

Singh Y (2003) Photosynthetic activity, and lipid and hydrocarbon production by alginate-immobilized cells of Botryococcus in relation to growth phase. J Microbiol Biotechnol 13:687-691

Steinman AD (1992) Does an increase in irradiance influ- 
ence periphyton in a heavily-grazed woodland stream? Oecologia 91:163-170

Tam NFY, Wong YS (2000) Effect of immobilized microalgal bead concentrations on wastewater nutrient removal. Environ Pollut 107:145-151

Thakur A, Kumar HD (1999) Nitrate, ammonium, and phosphate uptake by the immobilized cells of Dunaliella salina. Bull Environ Contam Toxicol 62:70-78

Thu B, Bruheim P, Espevik T, Smidsrǿd O, Soon-Shiong P, Skjåk-Bræk G (1996) Alginate polycation microcapsules: II. Some functional properties. Biomaterials 17: 1069-1079

Editorial responsibility: Alejandro Buschmann,

Puerto Montt, Chile
Travieso L, Benitez F, Dupeirón R (1992) Sewage treatment using immobilized microalgae. Bioresour Technol 40: 183-187

* Valeta J, Verdegem M (2015) Removal of nitrogen by algal turf scrubber technology in recirculating aquaculture system. Aquacult Res 46:945-951

* vanRijn J, Tal Y, Schreier HJ (2006) Denitrification in recirculating systems: theory and applications. Aquacult Eng 34:364-376

*Verdegem MCJ, Bosma RH, Verreth JAJ (2006) Reducing water use for animal production through aquaculture. Int J Water Resour Dev 22:101-113

Submitted: December 7, 2016; Accepted: April 28, 2017 Proofs received from author(s): June 10, 2017 